\title{
PEMANFAATAN LOKASI WISATA KULINER PAGARUYUNG SEBAGAI PENGENALAN IDENTITAS ETNIS TAMIL DI DAERAH KECAMATAN MEDAN PETISAH
}

\author{
GIOT MARITO BR MARBUN \\ Alumni Prodi. Pendidikan Antropologi Fakultas Ilmu Sosial Unimed \\ giotmaritomarbun@gmail.com
}

\begin{abstract}
Abstrak
Artikel ini merupakan hasil penelitian yang bertujuan menjelaskan proses pengenalan identitas etnis Tamil melalui lokasi wisata kuliner Pagaruyung dan juga menjelaskan tentang makanan khas Tamil yang dijual di kuliner Pagaruyung. Pendekatan yang digunakan dalam penelitian yang digunakan dalam artikel ini adalah dengan pendekatan deskriptif. Penulis menggunakan penelitian lapangan (field research) dengan bentuk observasi non partisipasi (non partisipan observer). Selain field research, penulis juga menggunakan teknik pengumpulan data antara lain yaitu: wawancara (interview), Observasi serta studi pustaka (library research), dan dokumentasi untuk menambah data yang relevan dengan penelitian yang dilakukan. Berdasarkan metode yang digunakan diperoleh hasil penelitian, kuliner Pagaruyung semakin banyak diminati wisatawan karena menu yang digunakan adalah khas Etnis Tamil, proses pengenalan kuliner Pagaruyung melalui media massa dan media social, kuliner yang ditawarkan mayoritas khas Tamil dan ada juga yang khas dari Kota Medan serta daerah lainnya dan keberadaan pariwisata di Kota Medan menjadi salah satu faktor pendukung perkembangan kuliner Pagaruyung sebagai lokasi wisata kuliner yang digunakan sebagai pengenalan identitas etnis Tamil terhadap para masyarakat. Kesimpulannya adalah bahwa keberadaan lokasi kuliner Pagaruyung sangat berpengaruh terhadap pengenalan identitas etnis Tamil. Dengan menjual berbagai makanan khas etnis Tamil, kuliner ini semakin dikenal oleh para pengunjung atau wisatawan local maupun interlokal. Berbagai media sudah meliput, menayangkan dan mengepost di berbagai media massa dan media sosial.
\end{abstract}

Kata Kunci: Identitas, Kuliner Pagaruyung, Etnis Tamil, Pariwisata

\section{PENDAHULUAN}

Medan merupakan salah satu kota yang memiliki bermacam-macam etnis dari berbagai pendatang seperti: Mandailing, Jawa, Batak Toba, Simalungun, Karo, Tionghoa dan Tamil. Setiap etnis tersebut juga memiliki kebudayaannya masing-masing yang dimana kebudayaan tersebut menjadi identitas utama terhadap orang-orang yang menganut etnis itu sendiri. Salah satu contoh dari kebudayaan tersebut ialah makanan khas atau biasa disebut dengan kuliner.

Etnis Tamil memiliki berbagai macam kuliner dengan ciri khas ciptaan mereka sendiri yang digunakan sebagai bentuk pengenalan etnis mereka dan menjadi sasaran tepat untuk berwisata kuliner di Kota Medan karena seperti kita ketahui bahwa Kota Medan merupakan salah satu kota yang dikenal dengan kulinernya dan tentunya bisa dijanjikan kepada para pecinta kuliner. Adapun lokasi wisata kuliner tersebut dikenal dengan nama Kuliner Pagaruyung yang terletak di jalan Pagaruyung Kecamatan Medan Petisah.

Lokasi ini sangat mudah ditemukan oleh para pengunjung asing apalagi warga Kota Medan karena letaknya yang sangat strategis berada di tengah-tengah kota Medan. Lokasi ini didirikan oleh Pemerintah Kota
Medan pada masa kepemimpinan Rahudman yang bekerjasama dengan produk Teh Botol Sosro dengan membebaskan biaya pajak tempat dengan syarat tidak boleh ada produk minuman lain yang dijual kecuali Teh Botol Sosro itu sendiri.

Lokasi Kuliner Pagaruyung ini pada mulanya di bangun khusus untuk masyarakat etnis Tamil yang digunakan sebagai mata pencaharian penduduknya, akan tetapi pada masa sekarang ini diluar etnis Tamil juga sudah ada yang menetap seperti etnis Tionghoa, Jawa dan juga Batak. Kampung Madras atau biasa disapa dengan sebutan Kampung Keling merupakan lokasi tempat tinggal para etnis Tamil yang berada di Jalan Pagaruyung dan biasanya dikenal oleh masyarakat adalah etnis yang memiliki kulit gelap atau hitam dengan anutan agama seperti Hindu, Kristen, dan juga Islam.

Pada waktu itu sebagian masyarakat Kota Medan belum mengetahui etnis Tamil yang berada di Kampung Keling, tetapi ketika pemerintah berinisiatif untuk mengalokasikan mereka para penjual makanan khas etnisnya sendiri maka Tamil pun semakin dikenal oleh banyak masyarakat pribumi bahkan mancanegara. Makanan khas Tamil tersebut diracik dengan rempahrempah yang asli dari etnis Tamil serta memiliki 
inisiatif dalam membentuk makanan dengan seunikuniknya dan memberikan nama makanan itu yang tentunya memiliki arti sendiri, membuat para masyarakat ingin tahu lalu mengunjunginya dan berwisata kuliner.

Kuliner Pagaruyung adalah suatu bentuk pengenalan terhadap identitas suku Tamil di Kota Medan, bisa dilihat dari para pengunjung yang datang rata-rata hanya ingin mengetahui makanan khas Tamil yang di jual di tempat ini. Makanan khas etnis Tamil yang disediakan di kuliner Pagaruyung ini beragam macam, seperti: nasi briyani, martabak India, martabak Mesir, roti tissue dan mie keling alias mie rebus ala Medan. Harganya bervariasi sekitar Rp. 20.000,sampai dengan Rp. 40.000,- satu porsinya, akan tetapi sudah bisa merasakan kenikmatan sesuai dengan dana yang sudah dikeluarkan. Walaupun sudah banyak etnis lainnya yang menjajakan kulinernya, akan tetapi kuliner Tamil ini tetap menjadi buruan utama para pengunjung dikarenakan bentuk penyajian, rasa dan ciri khas yang unik sehingga sangat menarik perhatian pengunjung.

Para wisatawan asing juga ada yang sengaja menempuh perjalanan jauh dari Negaranya untuk berwisata kuliner di kuliner Pagaruyung ini. Mulai dari Malaysia, Amerika, Thailand bahkan dari Negara India yang merupakan negara asli etnis Tamil itu sendiri pun juga ada yang sengaja datang untuk mencari makanan khas kebudayaan mereka di karenakan makanan ini tidak akan dimasak kalau tidak ada acara besar seperti pernikahan, upacara keagamaan serta hari-hari besar lainnya kecuali kematian. Sehingga menimbulkan rasa rindu untuk mengkonsumsi makanan yang menjadi identitas dari etnis Tamil tersebut.

Lokasi wisata kuliner Pagaruyung sangat berpengaruh bagi penganut etnis Tamil karena penduduk kota Medan bahkan wisatawan asing semakin mengetahui identitas asli etnis mereka melalui berbagai macam kuliner yang mereka miliki dan yang mereka bawa. Hal tersebut tentu sangat berpengaruh terhadap perkembangan etnis Tamil, selain etnis tersebut di kenal banyak orang etnis tersebut juga mendapatkan pandangan positif dari para wisatawan asing juga masyarakat pribumi. Adanya nilai gizi yang memicu kesehatan meningkat semakin membuat para pecinta kuliner tidak segan-segan untuk menyantap berbagai menu yang tersedia di kuliner Pagaruyung tersebut dan menambahkan nilai plus terhadap etnis Tamil selaku pihak utama pemilik kuliner unik di kota Medan.

Dalam penelitian ini, peneliti menggunakan sumber tulisan dan kajian kepustakaan yang berkaitan dengan penelitian. Adapun yang di temukan sumber bacaan yaitu melalui skripsi yang berjudul: "Falsafah Dayok Binatur Pada Masyarakat Simalungun (Studi di Pematang Raya, Kecamatan Raya, Kabupaten Simalungun)" oleh Rahyu Swisty Sipayung (2012). Skripsi ini menjelaskan bahwa dalam suku Batak Simalungun memiliki makanan adat, yang dikenal dengan Dayok Binatur/Dayok Naniatur. Dayok Binatur adalah sajian masakan yang terbuat dari daging ayam. Dayok Binatur berfungsi sebagai lauk makanan dan biasanya disajikan pada setiap upacara adat simalungun.
Selain itu tulisan lain dalam bentuk jurnal yang berjudul: "Pengaruh Brand Image terhadap Proses Pengambilan Keputusan Konsumen Jigoku Ramen Bandung" oleh Juviani (2014). Menurut seorang ahli pariwisata Andar Danova Goeltom, M.Sc. Bandung sudah di kenal sebagai pusat kuliner nusantara sejak tahun 1941, hal ini dikarenakan Bandung memiliki jumlah rumah makan terbanyak di Indonesia. Bukan hanya dari golongan masyarakat pencinta makanan saja yang sengaja datang ke Bandung akan tetapi banyak para tokoh nasional baik itu dari dalam negeri maupun luar negeri yang menyempatkan diri datang ke Bandung.

Namun, penelitian yang dimaksudkan oleh penulis adalah ingin melihat dan mengamati bagaimana pemanfaatan lokasi wisata kuliner Pagaruyung sebagai pengenalan identitas masyarakat Tamil di daerah Kecamatan Medan Petisah. Bagaimana proses pengenalan kulinernya, serta bagaimana cara-cara yang dilakukan oleh masyarakat Tamil dalam penyajian berbagai kuliner sehingga dapat menarik perhatian pengunjung. Maka dari itu penulis membandingkan hasil dari tulisan yang sudah dijelaskan sebelumnya.

Wisata kuliner adalah kegiatan yang dilakukan banyak orang dalam bidang kebutuhan makanan, untuk hiburan. Sensasi lidah tidak dapat ditipu dengan rasa nikmat dan lezat. Kemauan lidah berbeda dengan hasrat akan rasa lapar. Kalau rasa lapar dapat dipenuhi dengan makanan yang umum nasi dan sayur serta lauk. Namun sensasi lidah sudah termasuk style atau gaya hidup yang membutuhkan biaya dan harga mahal. Sering dan banyak orang mencari makanan khas hanya untuk kegiatan memenuhi sensasi lidahnya. Maka dari itu, disimpulkan bahwa perbedaan antara kuliner dan wisata kuliner tidaklah terlalu jauh. Kuliner adalah makanannya, sedangkan wisata kuliner adalah kegiatan untuk menikmati makanannya.

Kuliner Pagaruyung merupakan salah satu kuliner yang sangat menjanjikan bagi masyarakat kota Medan. Kuliner Pagaruyung ini sendiri dikelola oleh masyarakat asli etnis Tamil. Lokasi wisata kuliner Pagaruyung digunakan sebagai pendapatan yang membantu perkembangan ekonomi para masyarakat etnis Tamil. Selain itu, lokasi wisata kuliner ini juga digunakan sebagai salah satu sarana pengenalan dari identitas suku Tamil tersebut. Dengan didirikannya kuliner Pagaruyung ini, masyarakat Kota Medan mulai mengetahui secara perlahan-lahan bahwa etnis Tamillah yang berperan besar di dalamnya walaupun bukan etnis Tamil saja yang berperan sepenuhnya..

Kebudayaan menurut Coleridge dalam culture studi kebudayaan (2013:20) adalah sebuah proses yang tak berwujud nyata tetapi riil konsekuensikonsekuensinya, sebuah tujuan, sebuah cita-cita dan terutama sebuah kondisi pemikiran manusia daam kehidupan sosial yang harus dijaga, dilestarikan, dijadikan pedoman dan cita-cita yang diperjuangkan.

Koentjaraningrat, (2003: 74 ) mengatakan bahwa ada tiga wujud kebudayaan, yaitu :

1. Ideas: wujud tersebut menunjukann wujud ide dari kebudayaan, sifatnya abstrak, tak dapat diraba, 
dipegang ataupun difoto, dan tempatnya ada di alam pikiran warga masyarakat dimana kebudayaan yang bersangkutan itu hidup. Budaya ideal mempunyai fungsi mengatur, mengendalikan, dan memberi arah kepada tindakan, kelakuan dan perbuatan manusia dalam masyarakat sebagai sopan santun. Kebudayaan ideal ini bisa juga disebut adat istiadat.

2. Activities: wujud tersebut dinamakan sistem sosial, karena menyangkut tindakan dan kelakuan berpola dari manusia itu sendiri. Wujud ini bisa diobservasi, difoto dan didokumentasikan karena dalam sistem ssosial ini terdapat aktivitas-aktivitas manusia yang berinteraksi dan berhubungan serta bergaul satu dengan lainnya dalam masyarakat. Bersifat konkret dalam wujud perilaku dan bahasa.

3. Artifacts: wujud ini disebut juga kebudayaan fisik, dimana seluruhnya merupakan hasil fisik. Sifatnya paling konkret dan bisa diraba, dilihat dan didokumentasikan. Contohnya : candi, bangunan, baju, kain komputer dll.

Maka, teori kebudayaan yang dimaksudkan disini ialah bagaimana proses perwujudan suatu ide untuk menciptakan atau membuat makanan khas yang dimiliki oleh masyarakat etnis Tamil. Ketika masyarakat etnis Tamil sudah memantapkan ide yang mereka miliki, maka mereka melakukan suatu tindakan atau aktivitas guna untuk mengembangkan ide yang telah mereka miliki tersebut. Mengembangkan ide tersebut lalu mulai menciptakan makanan khas mereka dengan bahan rempah-rempah yang berasal dari etnis mereka sendiri serta merancang berbagai bentuk unik yang mampu memikat hati serta menarik pandangan mata. Setelah itu, masyarakat etnis Tamil mulai memperkenalkan pengembangan ide mereka dengan hasil karya yang telah mereka ciptakan yaitu berupa makanan khas di Kuliner Pagaruyung. Sedikit terasa asing di lidah masyarakat yang sama sekali belum pernah mencicipi makanan khas Tamil, akan tetapi ketika sudah dimulai mencicipi maka akan merasa ketagihan karena rempah-rempah serta bahan-bahan yang digunakan dan juga cara memasak untuk makanan tersebut merupakan khas dari etnis Tamil itu sendiri.

Teori identitas (identity theory) secara eksplisit lebih fokus terhadap srtuktur dan fungsi identitas individual, yang berhubungan dengan peran perilaku yang dilaksanakan di lingkungan masyarakat. Teori identitas sosial sendiri menyatakan bahwa identitas diikat untuk menggolongkan keanggotaan kelompok, "teori identitas sosial dimaksudkan untuk melihat psikologi hubungan sosial antar kelompok, proses kelompok dan sosial diri". Identitas bisa berbentuk kebangsaan, ras, etnik, kelas pekerja, agama, umur, gender, suku, keturunan, dan lain-lain. Biasanya, pendekatan dalam identitas sosial erat kaitannya dengan hubungan inter relationship, serta kehidupan alamiah masyarakat dan society (Hogg \& Abrams, 2000).

Menurut Sheldon Stryker (1980), teori identitas ini memusatkan perhatiannya pada hubungan saling mempengaruhi di antara individu dengan struktur sosial yang lebih besar lagi (masyarakat). Teori Stryker mengkombinasikan konsep peran (dari teori peran) dan konsep diri/self (dari teori interaksi simbolis). Bagi setiap peran yang kita tampilkan dalam berinteraksi dengan orang lain, kita mempunyai definisi tentang diri kita sendiri yang berbeda dengan diri orang lain, yang oleh Stryker dinamakan "identitas".

Maka, teori identitas yang dimaksudkan disini ialah bagaimana masyarakat etnis Tamil menyatukan setiap karya kebudayaan yang mereka miliki lalu memperkenalkannya kepada masyarakat luas mengenai apa yang mereka miliki dan menjadikan hasil dari karya mereka tersebut dalam bentu kuliner menjadi sebuah identitas yang membuat etnis Tamil semakin dikenal oleh masyarakat luas. Masing-masing individu yang bersatu dalam etnis Tamil saling bekerja sama untuk tetap melestarikan dan mempertahankan identitas kebudayaannya. Dalam hal ini tentunya diperlukan pengambilan peran oleh setiap individu agar identitas yang ingin dilestarikan dapat berjalan sesuai dengan yang diinginkan.

\section{METODE PENELITIAN}

Metode penelitian adalah langkah yang penting dalam suatu penelitian, karena pada pemilihan metode penelitian yang tepat akan menentukan keberhasilan di dalam suatu penelitian. Adapun jenis metode yang digunakan dalam penelitian ini adalah penelitian lapangan dengan pendekatan deskriptif yaitu dengan cara melihat dan mengamati secara langsung bagaimana sebenarnya pemanfaatan lokasi wisata kuliner Pagaruyung terhadap pengenalan identitas masyarakat Tamil di Kecamatan Medan Petisah. Menurut Bodgan dalam Moleong, 2005:4 bahwa metode kualitatif merupakan suatu metode yang menjadi prosedur penelitian dan menghasilkan data deskriptif berupa katakata tertulis atau lisan dari orang-orang dan perilaku yang diamati.

Adapun lokasi penelitian yang dipilih oleh peneliti yaitu di Jalan Pagaruyung Kecamatan Medan Petisah, Medan. Alasan peneliti memilih lokasi ini karena jalan Pagaruyung merupakan lokasi dimana Kuliner Pagaruyung ditempatkan dan berkembang sehingga menjadi suatu bentuk pengenalan terhadap identitas etnis Tamil.

Subjek penelitian adalah sesuatu yang diteliti baik orang, benda, lembaga atau organisasi (Afdhol Abdul: 2012). Subjek penelitian pada dasarnya adalah yang dikenai kesimpulan hasil penelitian. Subjek penelitian yang digunakan dalam penelitian ini adalah masyarakat Tamil yang bertempat tinggal di jalan Pagaruyung Kecamatan Medan Petisah untuk dapat memberikan informasi tentang penelitian manfaat kuliner Pagaruyung.

Menurut (Supranto 2000: 21) objek penelitian adalah himpunan elemen yang dapat berupa orang, organisasi atau barang yang diteliti. Objek yang digunakan dalam penelitian ini ialah orang-orang yang memberikan informasi langsung mengenai manfaat kuliner Pagaruyung terhadap pengenalan identitas 
masyarakat Tamil seperti para pengunjung dan juga para pedagang. Menurut Spradley dalam Sugiono (2009:297) dijelaskan bahwa dalam penelitian kualitatif tidak menggunakan populasi namun dinamakan dengan "sosial institusion" atau situasi sosial yang terdiri dari tiga elemen yakni tempat (place), pelaku (actors), dan aktivitas (activity).

Untuk mendapatkan hasil yang baik dari sebuah penelitian, maka di dalam penelitian dibutuhkan teknik dalam pengumpulan data. Maka peneliti menggunakan teknik sebagai berikut:

Observasi merupakan teknik pengumpulan data dengan cara mengamati secara langsung objek-objek yang akan diteliti. Observasi ialah sebuah rancangan ilmiah untuk menggambarkan realitas sebagai suatu kerangka yang diamati dan setelah itu akan ada usaha untuk menerjemahkan penemuan-penemuan tersebut ke dalam konteks. Dalam arti luas observasi adalah seorang peneliti yang secara terus menerus melakukan suatu pengamatan terhadap perilaku seseorang atau objek yang akan diteliti.

Wawancara adalah merupakan salah satu teknik pengumpulan data dalam melakukan suatu penelitian. Menurut (Moleong 2010: 186) wawancara adalah percakapan yang dilakukan dengan maksud tertentu dan dilakukan oleh dua pihak, yaitu pewawancara yang mengajukan pertanyaan dan terwawancara yang memberikan jawaban atas pertanyaan itu. Biasanya wawancara juga dapat diartikan sebagai cara peneliti untuk mendapatkan informasi dari responden dengan cara bertatapan muka langsung. Wawancara dilakukan oleh peneliti secara langsung kelapangan oleh penulis terhadap apa yang ingin diteliti dan maksud dari wawancara adalah untuk mengontruksi mengenai orang, kejadian, kegiatan, organisasi, perasaan, motivasi, tuntutan, kepedulian dan lain-lain.

Dokumentasi merupakan salah satu metode pengumpulan data yang digunakan dalam penelitian untuk mendapatkan data yang konkret dalam bentuk gambar. Gambar yang dimaksud dalam penelitian ini adalah gambar yang menyangkut kegiatan yang akan dilaksanakan oleh narasumber pada saat bekerja dan berkuliner di wisata kuliner Pagaruyung, maka peneliti dengan cepat melakukan penelitian untuk memperoleh data-data yang menyangkut masalah yang dibahas penulis dalam penelitian ini.

$$
\text { Analisa data merupakan proses }
$$

pengorganisasian dan mengurutkan data ke dalam pola kategori dan satuan uraian dasar sehingga dapat ditemukan tema dan dapat dirumuskan. Menurut Spradley (2006:131-132) langkah analisis bisa dilaksanakan setelah data-data dikumpulkan dengan langkah melalui wawancara, observasi, dan studi pustaka.

\section{HASIL DAN PEMBAHASAN Sejarah Etnis Tamil Datang Ke Kota Medan}

Kota Medan diwarnai dengan indahnya budaya berbagai etnis yang menempatinya. Tidak hanya etnis asli Indonesia, tetapi juga berbagai etnis pendatang seperti Tamil, Tionghoa, dan Arab yang telah bermukim di Indonesia sejak berabad silam yang telah menjadi bagian tak terpisahkan dengan kota ini.

Salah satu permukiman etnis pendatang di Kota Medan ialah kampung Keling atau Kampung Madras. Sebelum kemerdekaan Indonesia pada tahun 1945, rasa India di kawasan ini tercermin dari nama-nama jalan yang sampai kini beberapa di antaranya masih digunakan. Dulu nama Jalan Kalkuta, Jalan Bombay, Jalan Nagapatam, Jalan Ceylon, Jalan Madras bisa ditemukan di seputaran kawasan ini. Sekarang namanama itu sudah berganti beberapa tetapi nama-nama seperti Kelurahan Madras, Jalan PJ Nehru, Muara Takus, Candi Biara, Gajah Mada, Maja Pahit, Taruma, Candi Prambanan, Candi Borobudur, Majapahit yang semuanya masih bernuansa Hindu. Di Kampung Keling ini puluhan bangunan tua khas zaman kolonial Belanda masih bisa ditemukan di sini. Bangunan-bangunan ini adalah bangunan bersejarah peninggalan masa keemasan tembakau Deli. Di kawasan inilah dahulu masyarakat India tinggal dan bermukim.

\section{Pariwisata Di Kota Medan}

Kota Medan sebagai ibu kota provinsi memiliki tempat-tempat wisata yang menarik untuk dikunjungi sehingga kegiatan kepariwisataan lebih berpeluang untuk dikembangkan dibandingkan kota lainb yang ada di Sumatera Utara. Tempat-tempat bersejarah, bangunan-bangunan tua, museum, tempat ibadah, wisata jajanan, danau buatan dan sebagainya merupakan daya tarik tersendiri yang dapat dinikmati oleh setiap pengunjung yang dating ke Kota Medan.

\section{Proses Pengenalan Kuliner Pagaruyung}

Pada awalnya kuliner Pagaruyung tidak begitu dikenal oleh masyarakat, karena belum adanya tindakan publikasi dari etnis Tamil sendiri. Etnis Tamil mulamula berjualan hanya dengan cara coba-coba. Dengan membawa makanan khas etnisnya mereka mulai memamerkan serta menjual kepada masyarakat. Lalu setelah itu semakin banyak masyarakat etnis Tamil yang mulai membuka usaha mereka dengan berjualan sebagai mata pencaharian mereka demi melangsungkan kehidupannya. Akan tetapi, lokasi tempat mereka berjualan sama sekali belum dikenal oleh para masyarakat yang berada diluar kampong madras.

\section{Makanan Khas Sebagai Bentuk Pengenalan Identitas}

Setiap bangsa dimanapun berada pasti memiliki kebudayaan. Kebudayaan merupakan keseluruhan sistem gagasan manusia yang menghasilkan karya cipta didalam kehidupan manusia yang telah menjadi aktifitas secara terus menerus di lingkungan masyarakat melalui proses belajar. Kebudayaan mencangkup komplek ide, gagasan, nilai-nilai, norma-norma dan sebagainya komplek aktifitas atau tindakan pola hidup masyarakat dan benda-benda hasil karya manusia. 
Makanan merupakan salah satu komponen hasil kebudayaan yang diciptakan manusia yang terus mengalami perkembangan secara terus menerus sessuai dengan perkembangan zaman melaui proses belajar, perpaduan dengan bangsa lain, eksperimen, dan lain sebagainya. Sedangkan makanan khas adalah makanan yang biasa di konsumsi di suatu daerah. Karakter masakan di suatu daerah biasanya mencerminkan karakter masyarakatnya. Daerah pegunungan menghasilkan masakan dari sayur-mayur karena iklim pegunungan yang dingin, umumnya masakannya serba panas atau pedas, untuk menghangatkan badan. Penduduk di daerah pesisir sering kontak dengan orang asing atau daerah lain sehingga melahirkan banyak masakan campuran yang ikut memperkaya produk makanan khas daerah.

\section{Kuliner Yang Ditawarkan}

Berbagai macam kuliner ditawarkan di kuliner Pagaruyung tersebut yang dimana kuliner tersebut merupakan kuliner asli yang mereka bawa dari Negara mereka. Dan ketika mereka realisasikan melalui lokasi yang terletak di Jalan Pagaruyung ini, maka banyak wisatawan lokal maupun interlokal yang meminati kuliner khas Tamil tersebut, yaitu: Nasi Briyani, Nasi Samin, Nasi Goreng Bombay, Roti Tissue, Martabak Mesir, Martabak India.

\section{PENUTUP}

Berdasarkan pembahasan di atas maka dapat dirumuskan beberapa simpulan, diantaranya:

1. Kuliner merupakan sebuah gaya hidup yang tidak dapat dipisahkan karena setiap orang memerlukan makanan yang sangat dibutuhkan sehari-hari. Wisata kuliner adalah kegiatan yang dilakukan banyak orang dalam bidang kebutuhan makanan, untuk hiburan. Maka dari itu, perbedaan antara kuliner dan wisata kuliner ialah kalau kuliner adalah makanannya, sedangkan wisata kuliner adalah kegiatan untuk menikmati makanannya.

2. Kuliner Pagaruyung dikelola oleh masyarakat asli etnis Tamil dan bekerja sama dengan Pemerintah Kota Medan . Lokasi wisata kuliner Pagaruyung digunakan sebagai pendapatan yang membantu perkembangan ekonomi para masyarakat etnis Tamil. Selain itu, lokasi wisata kuliner ini juga digunakan sebagai salah satu sarana pengenalan dari identitas suku Tamil tersebut. Dengan didirikannya kuliner Pagaruyung ini, masyarakat Kota Medan mulai mengetahui secara perlahan-lahan bahwa etnis Tamil-lah yang berperan besar di dalamnya walaupun bukan etnis Tamil saja yang berperan sepenuhnya.

3. Makanan khas Etnis Tamil yang dijual di Kuliner Pagaruyung adalah martabak telur, martabak mesir, martabak India, mie rebus ala india atau biasa disebut dengan mie keling, nasi briyani, nasi samin, nasi goring Bombay dan roti tissue. Selain itu ada juga makanan yang berasal dari daerah Medan maupun daerah lainnya, yaitu sate, martabak, gadogado, bandrek, jus dan segala macam mie seperti mie aceh dan lainnya.

4. Identitas Tamil pada awalnya masih sangat minim untuk dikenal oleh masyarakat luas sehingga ide kreatif mulai dilaksanakan oleh etnis Tamil itu sendiri untuk memperkenalkan budaya mereka kepada masyarakat luas. Maka dengan didirikannya Kuliner Pagaruyung ini, para masyarakat di Kota Medan dan para wisatawan asing lainnya yang berdatangan dapat menikmati berbagai makanan khas budaya Tamil yang digunakan sebagai pengenalan identitasnya.

\section{Saran}

Adapun saran yang dapat penulis berikan adalah:

1. Para penjual yang berjualan di kuliner Pagaruyung sebaiknya harus lebih ramah lagi dalam melayani para pengunjung.

2. Kepada para orang tua sebaiknya tidak membiarkan anaknya yang masih kecil untuk ikut berjualan hingga larut malam karena akan mengganggu jam tidur dan jam belajarnya yang berpengaruh juga terhadap sekolahnya.

3. Dari segi lingkungan diharapkan kepada para penjual agar lebih memperhatikan kebersihan supaya lebih menarik lagi untuk dikagumi.

4. Pelayanan yang diberikan kepada wisatawan sebaiknya lebih ditingkatkan lagi, misalnya diasaat pemesanan supaya prosesnya tidak lama sehingga tidak timbul rasa bosan karena menunggu terlalu lama.

\section{DAFTAR PUSTAKA}

Causey, Andrew. 2006. Danau Toba. Medan: Bina Media Perintis

Geertz, Clifford, 1992. Tafsir Kebudayaan. Yogyakarta: KANISIUS

Jenks, Chris. 2013. Culture Studi Kebudayaan. Yogyakarta: Pustaka Pelajar

Moleong. 2010, Metodologi Penelitian Kualitatif. Bandung: Rosdakarya

Nasrullah, Rulli. 2012, Komunikasi Antarbudaya: Di Era Budaya Siberia. Jakarta: Kencana

Picard, Michael. 2006, Bali: Pariwisata Budaya dan Budaya Pariwisata. Jakarta: KPG (Kepustakaan Populer Gramedia)

Pelly, Usman dan Asih Menanti. 1994. Teori-teori sosial budaya. Jakarta: Direktorat Jendral Pendidikan Tinggi, Dinas Pendidikan dan Kebudayaan

Rangkuti, Freddy. 2009. Analisis SWOT Teknik Membedah Kasuss Bisnis. Jakarta: Gramedia 
Simanjuntak, B.A. 2006, Melayu Pesisir dan Batak Pegunungan. Jakarta: Obor Indonesia

Sinar, Tengku Luckman. 1991. Sejarah Medan Tempo Doeloe

Suwantoro, Gamal. 1997. Dasar-dasar Pariwisata. Yogyakarta: Andi

Widyanta, AB. 2002, Sosiologi Kebudayaan George Simmel. Yogyakarta: Cindelaras Pustaka Rakyat Cerdas

Febriansyah, Yudhis, Muhammad. 2014. Perkembangan Kerajaan Pagaruyung Diluhak Tanah Datar, Sumatera Barat (1349-1809). Skripsi mahasiswa Unimed

Harahap, Ramadhani, Yudhi. 2015. Inovasi Kuliner Magic Mashroom Pada Masyarakat Tuktuk Siadong Kecamatan Simanindo Kabupaten Samosir Sumatera Utara. Skripsi mahasiswa Unimed.

Kumar, Siwa. 2009. Komunitas Tamil di Kota Medan: Skripsi, Medan: Universitas Sumatera Utara

Simbolon, Maria Rini. 2012. Kerajaan Pagaruyung di Batusangkar. Skripsi Mahasiswa Unimed

Sipayung, Swisty, Rahyu. 2012. Falsafah Dayok Binatur Pada Masyarakat Simalungun (Studi di Pematang Raya, Kecamatan Raya, Kabupaten Simalungun). Skripsi mahasiswa Unimed.

Suryanto, Bagong; Sutinah. 2007, Metode Penelitian Sosial. Jakarta: Kencana

\section{Sumber Jurnal dan Makalah:}

http://repository.usu.ac.id/bitstream/123456789/37992/5 /Chapter\%20I.pdf (Diakses pada tanggal $24 \mathrm{Mei}$ 2015)

eprints.uny.ac.id/8715/3/BAB 2 - 08413241026.pdf (Diakses pada tanggal 24 Mei 2015)

Juviani. 2014. Pengaruh Brand Image terhadap Proses Pengambilan Keputusan Konsumen Jigoku Ramen Bandung. (Diakses pada tanggal 15 April 2015)

\section{Sumber Internet:}

http://digital_130005-T 26724-Studi kinerjaMetodologi. (Diakses pada tanggal 15 Mei 2015)

http://id.wikipedia.org/wiki/Makanan (Diakses pada tanggal 16 April 2015)

https://id.wikipedia.org/wiki/Kota_Medan (Diakses pada tanggal 9 Juli 2015)

https://konsultasikehidupan.wordpress.com/2009/05/12/ teori-identitas-identity-theory/ (Diakses pada tanggal 24 Mei 2015)

http://krisistia.blogspot.com/2013/03/a-pengertianidentitas-atau-jati-diri.html, (Diakses pada tanggal 15 April 2015)

http://pemkomedan.go.id/new/ (Diakses pada tanggal 9 Juli 2015)

http://rais-gaffar-046.blogspot.com/2013/07/50makanan-indonesia-paling-enak-lezat.html, Diakses pada tanggal 15 April 2015)

http://wisata.kompasiana.com/kuliner/2013/08/25/Paga ruyung-surga-kuliner-malam-di-medan586980.html, (Diakses pada tanggal 15 April 2015)

https://www.google.co.id/url? sa $=t \& r c t=j \& q=\&$ esrc $=s$ $\&$ source $=$ web $\& c d=3 \& c a d=r j a \&$ uact $=8 \& v e d=0 C C$ wQFjAC\&url=https\%3A\%2F\%2Fmohiyosrosyid.fil es.wordpress.com\% $\% 2011 \% 2 F 12 \% 2 F 0$ antropologi-dan gizi. (Diakses pada tanggal 15 April 2015)

http://www.organisasi.org/1970/01/daftar-namakecamatan-kelurahan-desa-kodepos-di-kota-medansumatera-utara-sumut.html (Diakses pada tanggal 16 Juli 2015) 